\title{
USE OF ICT TO ENHANCE THE LEARNING Process IN Higher EdUCATION
}

\author{
${ }^{1}$ Chetlal Prasad and ${ }^{2}$ Pushpa Gupta \\ ${ }^{1}$ MaaVindhyavashini Post Graduate College of Education \\ ${ }^{2}$ MVCE Padma, Hazaribag Vinoba Bhave University
}

\begin{abstract}
ICTs in Education refers to the development of information and communications technology specifically for teaching/learning purposes, while the ICTs in education involves the adoption of general components of information and communication technologies in the teaching learning process. The National Mission on Education through Information and Communication Technology (NME-ICT), launched in 2009 by the Central Government. Let's see how Information and Communication Technology (ICT) evolved the Higher Education system: The role of ICT in higher education, what students learn, The role of ICT in Higher Education, how Students Learn, The role of ICT in Higher Education, when students learn, The role of ICT in higher education, where students learn. Online courses, development of e-content, e-learning, digital libraries, online encyclopaedias, journals, and books would promote learning and make knowledge available to all irrespective of the distance or location or financial resources. Government intervention is necessary so that ICT can be made successful in higher education. Information and Communications Technology (ICT) has the proven power to change the world. This acronym refers to the merging of audiovisual and telephone networks with the computer single unified system of cabling.
\end{abstract}

\section{INTRODUCTION}

Information and Communication Technology (ICT) in higher education can revolutionise the education sector in India, thereby making its impact felt in other areas like governance, economy and administration. The National Mission on Education through Information and Communication Technology (NME-ICT), launched in 2009 by the Central government, seeks to provide connectivity across the country. The use of ICT can help the educator to use different modes of teaching, which will subsequently help students to keep the text or the issues involved in it, in their minds, perhaps, throughout their lives. But this depends not merely on the use of ICT but also the student and the educator. ICT tools would help students comprehend the text and would improve their proficiency. ICT tools can also help in making students attentive and interested. The goal of access, equity and quality is ensured through this mission. The focus is on integration of the use of ICT tools in higher education, which is the thrust of NME-ICT, will help bridge the digital divide. Use of ICT in higher education in the field of engineering, medical science, accountancy, management, business administration, computer science, information technology can be easily thought of. But what about the use of ICT tools in the so called 'traditional' subjects of history, literature, political science, economics and other areas of humanities. In this paper, ICT can enhance the teaching by doing away with boredom and making the students interested in what is being taught. It can motivate and keep the students engaged because ICT tools work at different levels - the students can have an opportunity to see, read, visualize, hear, ponder, discuss, interact and learn. This can be achieved through various means involving ICT. ICT is crucial to supplement the conventional or traditional mode of education. The word 'supplement' here is important, because technology cannot replace the teacher as such. The use of ICT can supplement or add to the traditional mode. In the present context of technology and information 
boom, traditional mode of teaching seems monotonous and in most of the colleges and universities across the country

Information and Communications Technology (ICT) has the proven power to change the world. This acronym refers to the merging of audio-visual and telephone networks with the computer single unified system of cabling. Thus, ICT includes any communication device - including radio, television, cell phones, computer and network hardware, satellite systems, etc. Today, ICT technologies have embedded themselves as commonplace entities in all aspects of life. This gives us further evidence that the world is rapidly moving towards increased adoption of digital technology.

The role of ICTs in education is becoming more and more critical. The higher education sector has advanced with the help of various ICT tools such as smart devices, smart boards, online classrooms, digital cameras, projectors, video conferencing tools, audio recording tools, and many more. However, ICT has benefited the higher education sector in more than just new tools. The use of ICT in higher education will help in increasing the GER (Gross Enrolment Rate) of India. The increase in the GER would bring in equity and access in the field of education. Equity in education in a sense implies bridging the digital divide. The more the enrolment rate in higher education through distance or regular mode, the faster will be the process of bridging the digital divide.

Online courses, development of e-content, e-learning, digital libraries, online encyclopaedias, journals, and books would promote learning and make knowledge available to all irrespective of the distance or location or financial resources. If the required ICT infrastructure is present or made available in remote parts of the country, then the resources mentioned above would be available in rural India as well. Since India is a huge country, with more area under rural rather than urban population, it is only through ICT that higher education can be made available to all the villages of the country. The step to provide ICT in the universities and colleges is indeed a laudable initiatory step. Moreover this will lead to the trickling down effect and would be able to encompass schools as well.

Under NME-ICT polytechnic or vocational skill development institutes have been encompassed. This step would help in bringing students and unemployed youths under the purview if ICT and enhance their learning skills and hence development. This would also ensure that more students enrol in these institutes. This too would lead to the bridging of the digital divide. ICT would support collaboration in different programmes on higher education from different parts of the country and the world. The space would be opened wide for all. Collaborative programmes between different institutes will prove fruitful as there will be opportunity for video conferencing, sharing of resources and other activities.

Last, but not the least, research scholars can make use of ICT tools to carry forward their research. They not only can have access to works done in their field of interest but also use ICT tools in presenting papers during seminars, conferences and discussions. This would hone their skills as well as make them adept in using these tools and compete in the international field. This would not only help in bridging the digital divide but also help in the development of the country. In order to bridge the digital divide, it is very important that ICT tools are integrated into the education system and that these are accessible to all. Training of teachers in using ICT tools is of utmost importance, so is its effective usage. If ICTs are not accessible, or are not used in an appropriate manner, it would not be possible to make NME-ICT a success nor would it be possible to bridge the digital divide. 


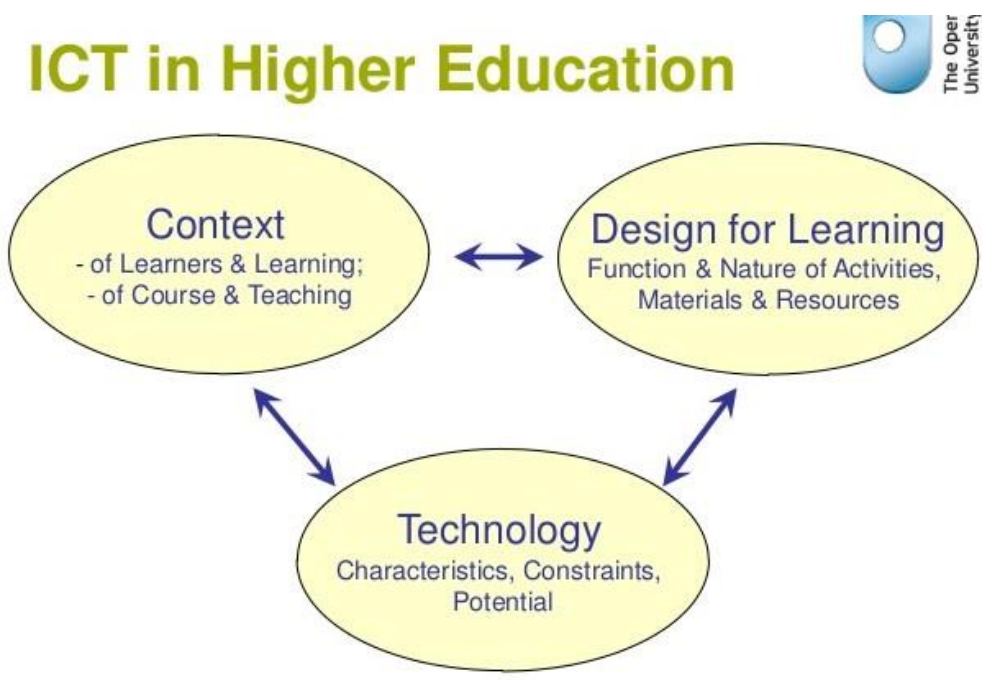

Let's see how Information and Communication Technology (ICT) evolved the Higher Education system:

\section{The Role of ICT in Higher EduCATION, What StUdents Learn}

Traditional teaching has revolved around content with great emphasis laid on textbook-based learning. The teachers headed the classroom and used lectures, tutorials, and presentations to help the students understand the material being taught. With the introduction of ICT and various Edu. Tech. tools, students are no longer restricted to learning from the textbook, class lectures, and presentations. With the help of the internet and ICT tools, higher education learners can access a variety of sources for information, including videos, documentaries, podcasts, and speeches by experts.

\subsection{The Sources of Learning are Endless}

The onus of learning has also shifted from teachers to the students as there is an increased focus on student-cantered learning that is based on the access of information. This has also changed the role of the teachers from being content experts to being guides and mentors for the students. It is opined that as students and teachers gain access to higher bandwidths on internet connectivity and more direct forms of communication, the trend of student-driven learning will continue to grow in higher education institutes.

\section{The Role of ICT in Higher EduCATION, How StUdents Learn}

ICT is not only influencing, changing, and supporting the content that is being learned in higher education institutes but also changing the way students are learning. There has been a systematic movement from content-cantered curricula to a competency-based curricula with the aid of various ICT tools. Similarly, there is a movement away from teacher-cantered learning to student-cantered forms of knowledge. ICT has facilitated a modern learning approach where students are encouraged to take responsibility for their own learning. Students are increasingly turning towards the web and online subject matter experts from who they will learn, thus creating an environment of independent learning. 


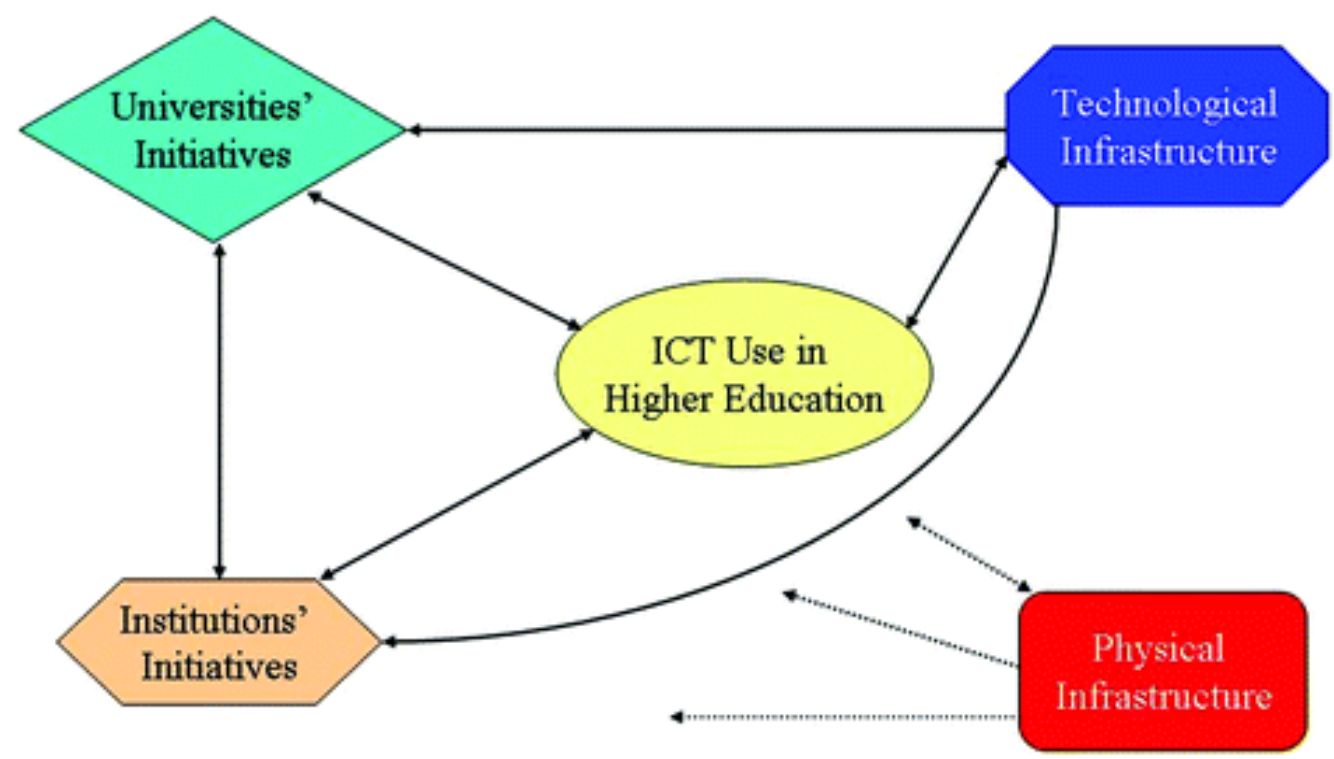

\section{The Role of ICT in Higher EduCATION, When STUdents LearN}

In traditional high schools, colleges and universities, institutions provided minimal choice for students for when the learning would take place. Typically, the students would accept the learning schedule prepared by the institute and follow the same.

The use of ICT tools allows students to optimize their learning experience by choosing when they wish to study based on their routine or body clock. Learners are free to participate in learning activities when time permits or be assured of no interruption. This freedom and flexibility have significantly increased the opportunities for many students to participate in formal programs. It has also provided learning opportunities for many more learners who previously were constrained by other commitments. The use of online technology learning has enabled learning to become an activity that is no longer set within programmed schedules and slots.

The various technologies can provide asynchronous support for learning so that the need for realtime participation is avoided while the students can benefit from the communication and collaboration that the online system provides. It is not only students, but even teachers benefit from these tools as they can decide what periods in the field can be utilized for teaching and interacting with the students. 


\section{REASONS TO USE ICT IN EDUCATION}

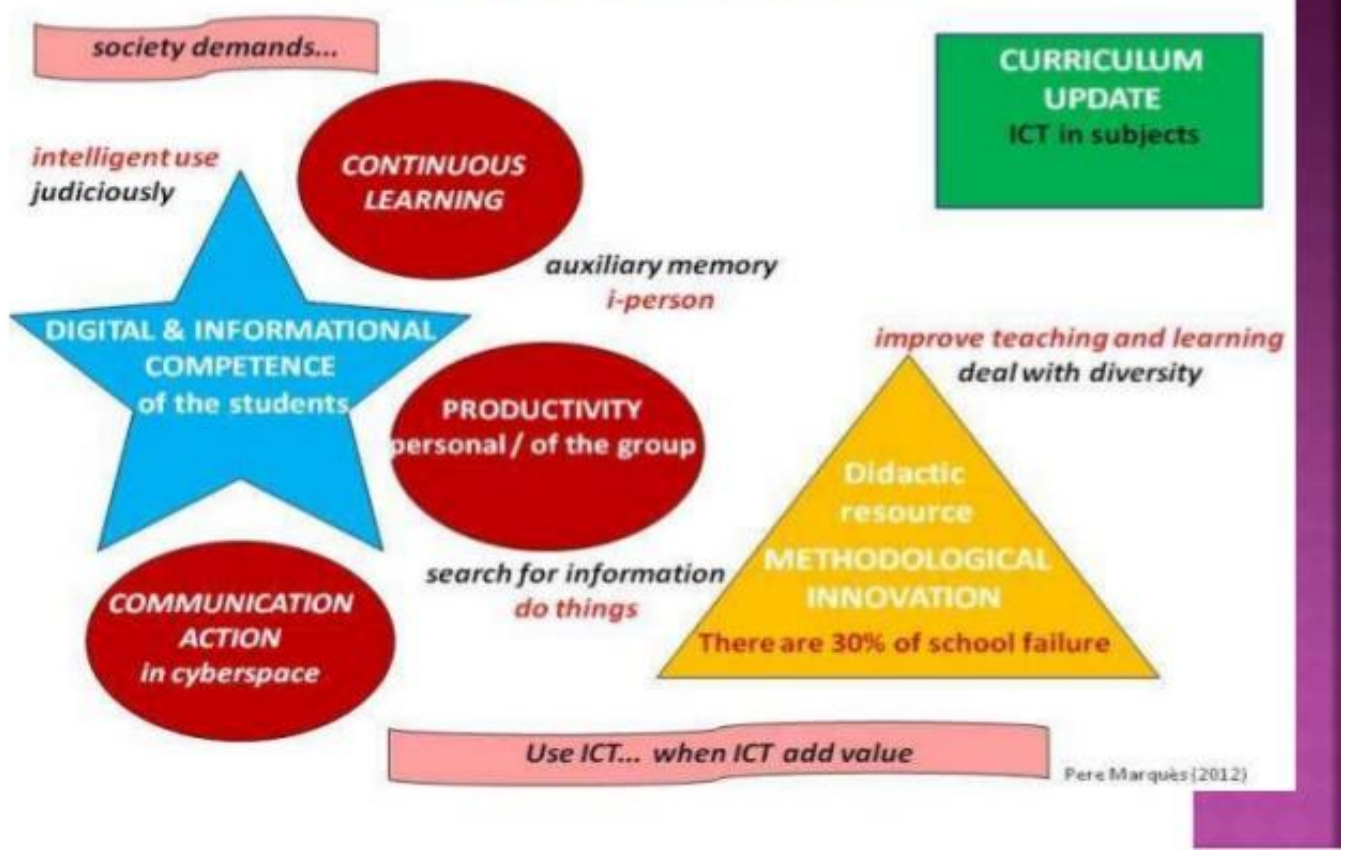

\section{The Role Of ICT In Higher Education, Where Students Learn}

The continued and increased use of ICTs has also changed where the students learn.

While the concept of flexibility in the location of education is not new to the prevalence of distance education programs for years. Yet, for most institutes, students do not choose the place of their location. With ICT and advancements in Educational Technology (ET) tools, off-campus delivery of courses is an option for students who were unable to attend the class for any number of reasons. Additionally, the use of ICT tools instead of a traditional classroom setting has given way to learning in work-based settings with students able to access courses and programs from their workplace. The advantages of education at the location of choice is not only increased convenience to the students but also financial savings and time-related savings with travel.

The concept of technology powered 'any place learning' also ensures that learners enrol in courses offered by any institute across the world rather than only applying for local educational institutes. The advantages of this include extended course offerings and the opportunity to digitally interact with co-learners and students from differing backgrounds, cultures, and perspectives. 'Connectivity' is a key-word when we talk about ICT. But there are a lot of questions which needs to be attended to while talking about ICT and connectivity. First is whether people are interested in using ICT tools. Next is whether the required infrastructure is available to them. Then, if it is available, are they competent enough to use them and derive benefit out of them. Government intervention is necessary so that ICT can be made successful in higher education. And NME-ICT undertaken by the government of India seems to be in the right direction. It focuses on access, skill development, training, quality, building infrastructure and equity. Through ICT, problems of the students can be attended to easily. The way online shopping sites respond to customer grievances, through ICT student grievances too can be answered. Moreover, ICT in higher education would provide employment to a number of unemployed youths in the country. 


\section{Conclusion}

Thus we may conclude that ICT is an important tool which has the potential to make the teaching and learning of 'traditional' subjects like social sciences or to be broader, teaching of higher education subjects specially professional subjects in any experience. It would help in revitalizing the importance of such subjects by various means. The means mentioned above are only suggestions and not exhaustive. A lot more can be done with the opinions of experts in the field of ICT. The present government policy, NME-ICT seems to be on the right track. It would help bridge the digital divide to a certain extent and also help in the growth and development of the country by building up human resource and providing employment. Some of the ways by which the digital divide within the country and in the international scenario can be bridged are enumerated. But it should be kept in mind that bridging the digital divide is a complex issue and NME-ICT can be seen as a preliminary step towards this goal.

Also higher education systems have grown exponentially in the past few decades to meet the increasing demands of quality education. The swift advancements in ICT have also helped to propel the higher education sector to serve the students and teachers better.

Today, ICT applications can provide many options and choices and for the students and institutes can create competitive edges by offering these choices to their students.

\section{REFERENCE}

1. http://www.sakshat.ac.in/

2. http://www.nitttrc.ac.in/

3. http://www.it.iitb.ac.in/nmeict/home.do

4. http://archive.excellencegateway.org.uk/page.aspx?o=ferl.aclearn.resource.

5. Bhatter College Journal of Multidisciplinary Studies, (ISSN 2249-3301), Vol. II,

6. Book Review of Panorama: A Collection of Short Stories by Shilpi Chaklanob is Governance and Management of Higher Education in India: an Overview

7. Sanyal, B. C. (2001), 'New functions of higher education and ICT to achieve education for all', Paper prepared for the Expert Roundtable on University and Technology-for- Literacy and Education Partnership in Developing Countries, International Institute for Educational Planning, UNESCO, September 10 to 12, Paris.

8. Sharma, R. (2003), 'Barriers in Using Technology for Education in Developing Countries', IEEE07803-7724-9103.Singapore schools', Computers \& Education.

9. UNESCO (2002) Information and Communication Technology in Education-A Curriculum for Schools and Programme for Teacher Development. Paris: UNESCO.

10. UNESCO,(2002),'Open And Distance Learning Trends, Policy And Strategy Considerations',14 UNESCO.

11. Report of AISHE Ministry of Education Govt. of India. 